\title{
War and Peace: The Evolution of Modern Personnel Administration in U.S. Industry
}

\section{Citation}

Baron, James N., Frank R. Dobbin, and P. Devereaux Jennings. 1986. War and peace: The evolution of modern personnel administration in U.S. industry. American Journal of Sociology 92(2): 350-383.

\section{Published Version}

http://dx.doi.org/10.1086/228504

\section{Permanent link}

http://nrs.harvard.edu/urn-3:HUL.InstRepos:3293074

\section{Terms of Use}

This article was downloaded from Harvard University's DASH repository, and is made available under the terms and conditions applicable to Other Posted Material, as set forth at http:// nrs.harvard.edu/urn-3:HUL.InstRepos:dash.current.terms-of-use\#LAA

\section{Share Your Story}

The Harvard community has made this article openly available.

Please share how this access benefits you. Submit a story.

Accessibility 


\title{
War and Peace: The Evolution of Modern Personnel Administration in U.S. Industry
}

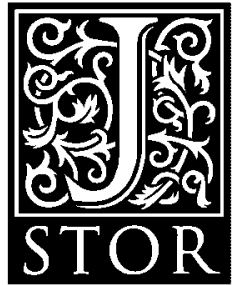

\author{
James N. Baron, Frank R. Dobbin, P. Devereaux Jennings \\ American Journal of Sociology, Volume 92, Issue 2 (Sep., 1986), 350-383.
}

Your use of the JSTOR database indicates your acceptance of JSTOR's Terms and Conditions of Use. A copy of JSTOR's Terms and Conditions of Use is available at http://www.jstor.org/about/terms.html, by contacting JSTOR at jstor-info@umich.edu, or by calling JSTOR at (888)388-3574, (734)998-9101 or (FAX) (734)998-9113. No part of a JSTOR transmission may be copied, downloaded, stored, further transmitted, transferred, distributed, altered, or otherwise used, in any form or by any means, except: (1) one stored electronic and one paper copy of any article solely for your personal, non-commercial use, or (2) with prior written permission of JSTOR and the publisher of the article or other text.

Each copy of any part of a JSTOR transmission must contain the same copyright notice that appears on the screen or printed page of such transmission.

American Journal of Sociology is published by University of Chicago Press. Please contact the publisher for further permissions regarding the use of this work. Publisher contact information may be obtained at http://www.jstor.org/journals/ucpress.html.

American Journal of Sociology

(C1986 University of Chicago Press

JSTOR and the JSTOR logo are trademarks of JSTOR, and are Registered in the U.S. Patent and Trademark Office. For more information on JSTOR contact jstor-info@umich.edu.

(C)2000 JSTOR

http://www.jstor.org/

Fri Aug 18 17:09:01 2000 


\title{
War and Peace: The Evolution of Modern Personnel Administration in U.S. Industry ${ }^{1}$
}

\author{
James N. Baron, Frank R. Dobbin, and P. Devereaux Jennings \\ Stanford University
}

\begin{abstract}
This paper charts the transformation of the employment relationship in different industries during the second quarter of this century and is based on a representative sampling of U.S. business organizations. The first section documents changes in the control systems that prevailed in U.S. industries between the Depression and the end of World War II. The descriptive analyses generally corroborate portraits that have recently been provided by neo-Marxists of how and where technical and bureaucratic controls evolved. The second section sketches an explanation for the rapid diffusion of bureaucratic controls that apparently occurred between 1939 and 1946. It examines the role of three key constituencies in shaping modern systems of work force control: labor unions, personnel professionals, and the state. In particular, the analyses underscore the large role of government intervention in manpower activities during World War II in bureaucratizing employment. This effect of the state blurs the distinction between "efficiency" and "control" explanations of bureaucratic controls and internal labor markets, calling attention to institutional sources of change in organizations' employment structures. The concluding section highlights the implications of the findings for efforts to understand the employment relationship.
\end{abstract}

Recent research has examined how organizational and institutional arrangements shape labor market outcomes, rekindling interest in how and why employment practices vary across sectors of the economy. Differences among firms and industries in work arrangements, control systems, and the presence of internal labor markets are claimed to account for

\footnotetext{
${ }^{1}$ We gratefully acknowledge generous research support provided by the Stanford Graduate School of Business. Teri Bush provided invaluable assistance in preparing the manuscript. Suggestions from H. Aldrich, R. Althauser, Y. Cohen, P. DiMaggio, T. DiPrete, N. Fligstein, M. Hannan, S. Jacoby, T. Kochan, J. Meyer, D. Palmer, J. Pfeffer, G. Strauss, and $A J S$ reviewers were very helpful. Requests for reprints should be sent to James N. Baron, Graduate School of Business, Stanford University, Stanford, California 94305-5015.
}

(C) 1986 by The University of Chicago. All rights reserved. 0002-9602/87/9202-0003\$01.50 
career inequalities by age, sex, race, and ethnicity (see Hodson and Kaufman 1982). Researchers studying organizations have also been concerned with the evolution of workplace control and internal labor markets, although for slightly different reasons: their interest is in the origins of hierarchy and bureaucracy. Economists and organization theorists have traditionally viewed modern bureaucratic arrangements as rational and efficient. Others-particularly neo-Marxists-regard hierarchy and internal labor markets as elements of a "bureaucratic control" system that co-opts workers by reducing disserit and solidarity. ${ }^{2}$

Efficiency and control theories, however, involve some similar explanations of the evolution of bureaucratic employment arrangements. Divergent theories sometimes point to the same causes but interpret the underlying mechanisms differently. For instance, Marxists highlight a "crisis of control" occasioned by increasing organizational scale in American enterprise (Gordon, Edwards, and Reich 1982, p. 175), whereas orthodox organization theorists stress the technical and administrative superiority of bureaucracy in large organizations (e.g., Blau and Schoenherr 1971). Gordon et al. also emphasize employers' attempts earlier this century to reduce turnover as technologies became more sophisticated, costly, and susceptible to disruption. This factor too is discussed by various efficiency theorists, who highlight the transaction costs associated with replacing workers who command firm-specific skills (Doeringer and Piore 1971; Williamson 1975). Finally, neo-Marxists have emphasized management's desire to forestall or weaken unionization by vesting control in impersonal technical and administrative arrangements. Here too their historical portrait overlaps with other accounts. For instance, institutionalists since Slichter (1919) have traced modern personnel practices to union avoidance efforts. However, these authors typically assert that bureaucratic practices were not forced on labor conspiratorily or malevolently; rather, "workers had strong interests in the characteristic bureaucratic features of the internal labor market" (Jacoby 1984, p. 57; also see Steiber 1959; Kahn 1976; Rubery 1978; Elbaum 1984). Consequently, it is not easy empirically to distinguish portraits of the employment relation that emphasize imperatives of social control from accounts emphasizing organizational efficiency and rationality.

In short, increased interest in the consequences of contemporary employment systems has renewed theoretical debates about their origins. As a result, there has been a recent flowering of historical research on the

${ }^{2}$ This paper occasionally uses the phrase "bureaucratic control" in referring to a cluster of personnel practices that neo-Marxists view as integral to that system, such as centralized personnel functions, job evaluation, and the like. However, we do not mean to imply that those personnel practices were necessarily effective as control devices, which is an empirical question beyond the scope of this paper. 
advent of modern personnel practices. This paper extends this research by charting the transformation of the employment relationship during the second quarter of this century. We first describe changes in the prevalence of personnel practices in U.S. business firms from the Depression to the years following World War II. Past historical studies have described changing employment systems in specific industries, such as iron and steel (Steiber 1959; Stone 1974; Elbaum 1984) or chronicled changes in the U.S. economy (or manufacturing sector) as a whole (e.g., Clawson 1980; Gordon et al. 1982; Lawrence 1984; Jacoby 1985). Our analyses, in contrast, are based on several large and comprehensive surveys of U.S. corporations across diverse industries. Our findings generally corroborate and extend the results of previous historical analyses and case studies of how and where "bureaucratic control" developed.

We first describe the data sources used to chart the transformation of personnel practices. Then, after considering various efficiency and control accounts of the modern employment relation, we sketch an institutional explanation of the spread of bureaucratic controls during and after World War II. In particular, we focus on the role of three key constituencies in shaping modern systems of work force control: labor unions, personnel professionals, and the state. Our analyses underscore how government intervention in labor markets during World War II helped bureaucratize employment, just as "pressures from wartime government agencies had played a large part in fostering specialized employment departments during World War I" (Kochan and Cappelli 1984, p. 138; see also Harris 1982, p. 160). This effect of the state further blurs the distinction between efficiency and control perspectives by calling attention to institutional sources of change in organizations' personnel systems (Meyer and Brown 1977; Tolbert and Zucker 1983). We also describe how personnel professionals spearheaded attempts to extend bureaucratic controls after World War II.

\section{DATA AND METHODS}

The Sample

To describe changes in employment practices, we analyze data gathered by the National Industrial Conference Board (hereafter, NICB) ${ }^{3}$ in 1927, 1935, 1939, and 1946 (NICB 1927; 1928; 1936; 1940; 1947). The NICB publications based on these studies tabulate the prevalence of specific personnel practices by industry. Unfortunately, firm-level data were not

${ }^{3}$ This organization has since changed its name to the Conference Board. 
available; our results may therefore suffer from aggregation biases (Hannan 1971). In fact, the industrial designations are so broad for the 1927 survey that we employ those data only minimally.

The NICB attempted to survey the entire population of organizations in the industries listed in table 1, using companies listed by the New York Stock Exchange, Dun and Bradstreet publications, and other firm listings as sampling frames. The 1935 sample included 2,452 firms, which employed 4.5 million workers, $15.5 \%$ of the national labor force in these industry classifications at the time (NICB 1936, p. 5). The 1939 survey covered 2,700 firms with 5 million employees, and the 1946 survey covered 3,498 firms with an unspecified number of employees. Mean firm size was 1,836 and 1,847 in the 1935 and 1939 samples, respectively, demonstrating the prevalence of large companies in these surveys. Small enterprises, however, were by no means excluded: $33 \%$ of firms had fewer than 250 employees in 1935, as did $32 \%$ and $25 \%$ in 1939 and 1946, respectively. The fact that the 1946 sample contained a lower percentage of small firms may reflect real changes in mean U.S. firm size during World War II (see, e.g., U.S. Bureau of the Census 1950, p. 23). The mix of industries remained fairly constant across surveys; the largest number of firms was in steel and metalworking, and $80 \%-85 \%$ of the firms were in manufacturing in each sample. Moreover, the NICB samples included many of their member organizations, and the same organizations often participated in the various surveys over the years. Thus, while these data by no means constitute a panel study, there appear to be considerable continuity and comparability across surveys.

It is difficult to estimate precisely how representative these samples are of the population of U.S. business firms as a whole, since only establishment-level data are available from government sources during this period (see Granovetter 1984). We compared the size and regional distribution of manufacturing firms in the NICB sample against the population of U.S. manufacturing enterprises. This comparison suggests that the NICB samples overrepresented large northeastern firms (NICB 1936, p. 8; U.S. Bureau of the Census 1938, p. 20). Moreover, some industries with bimodal size distributions-particularly food (large production plants vs. small proprietorships), banks (commercial banks vs. savings and loans), insurance (companies vs. local brokers), and trade (department stores vs. family groceries) - exhibit higher average sizes in the NICB samples than in the population. Thus the NICB samples almost certainly represent larger corporations in these industries better than they do the many smaller ones.

The fact that the samples are biased toward large northeastern firms is due partly to a limited sampling frame but also undoubtedly to response 
TABLE 1

Percentage of Firms in Selected Industries Having Personnel Practices Related to Internal Labor Markets: 1927, $1935,1939,1946$

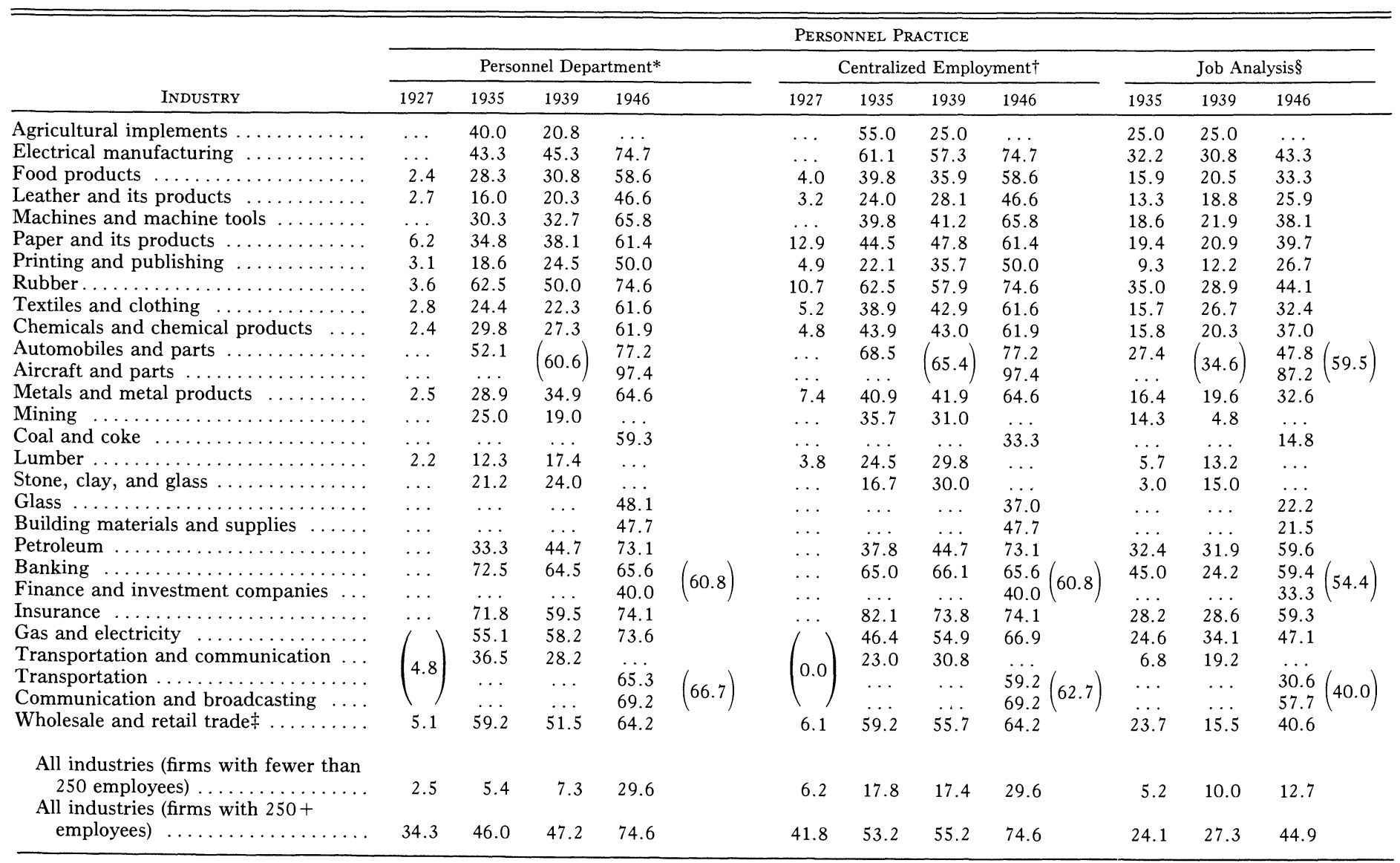




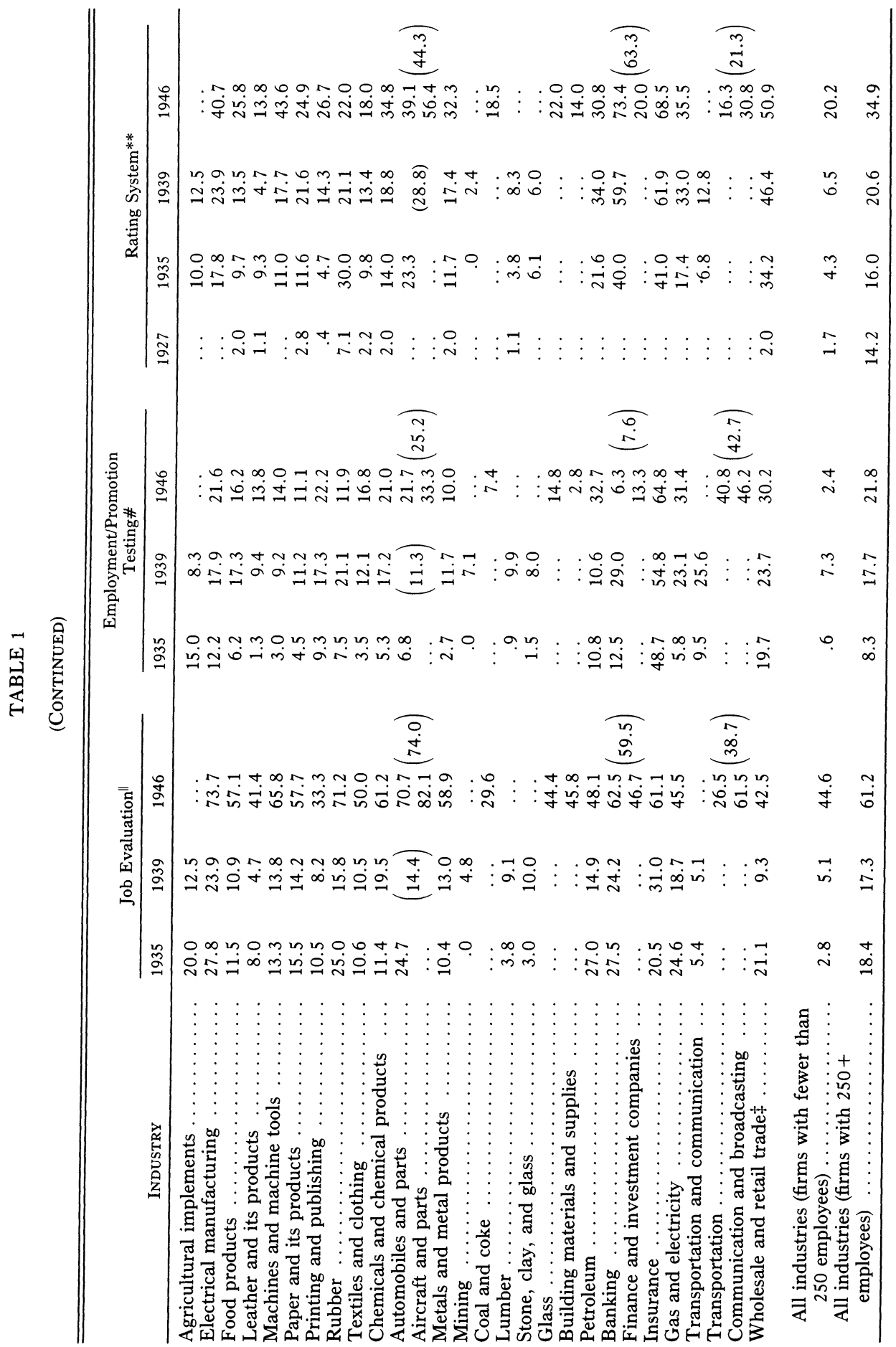




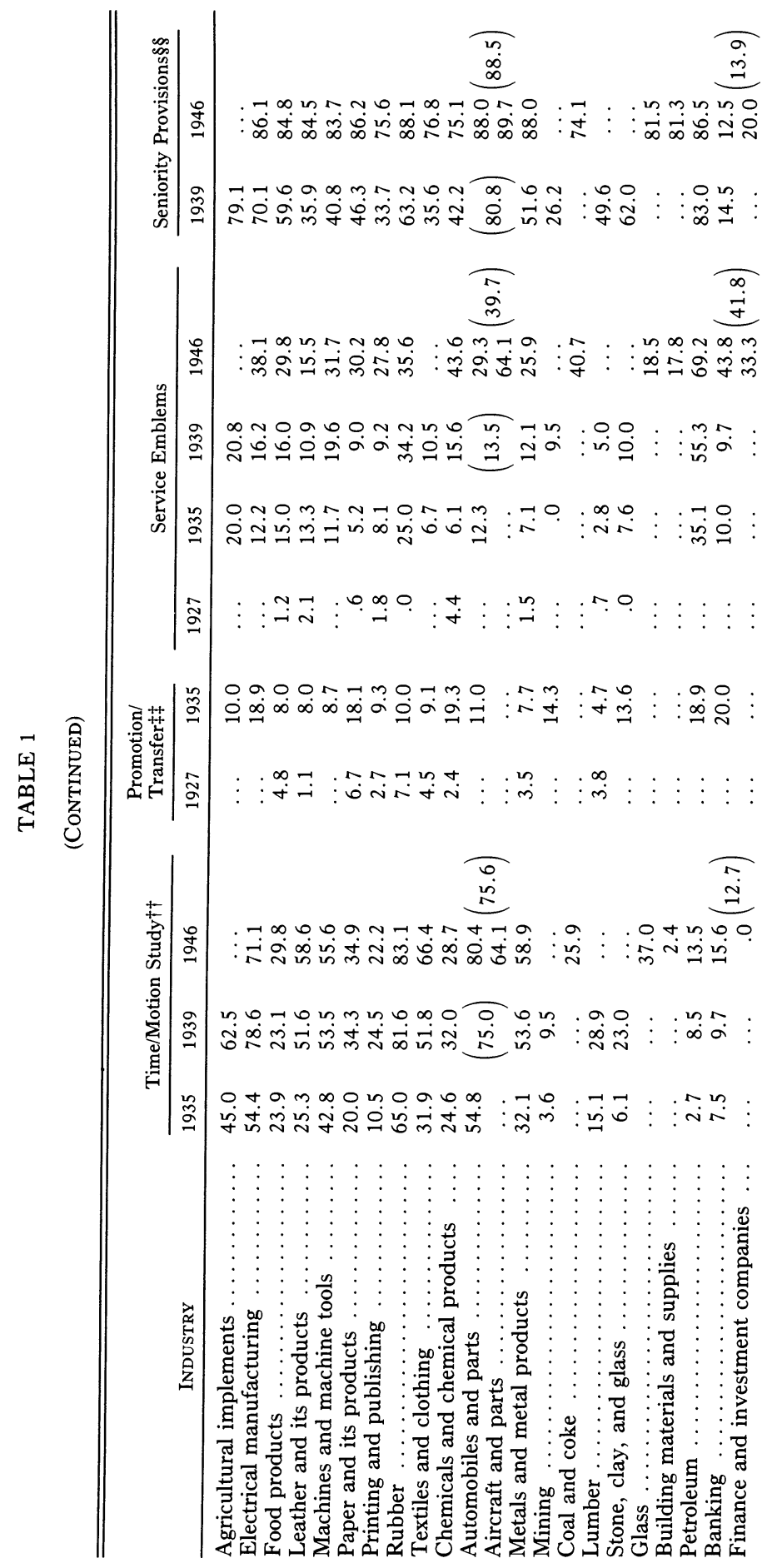




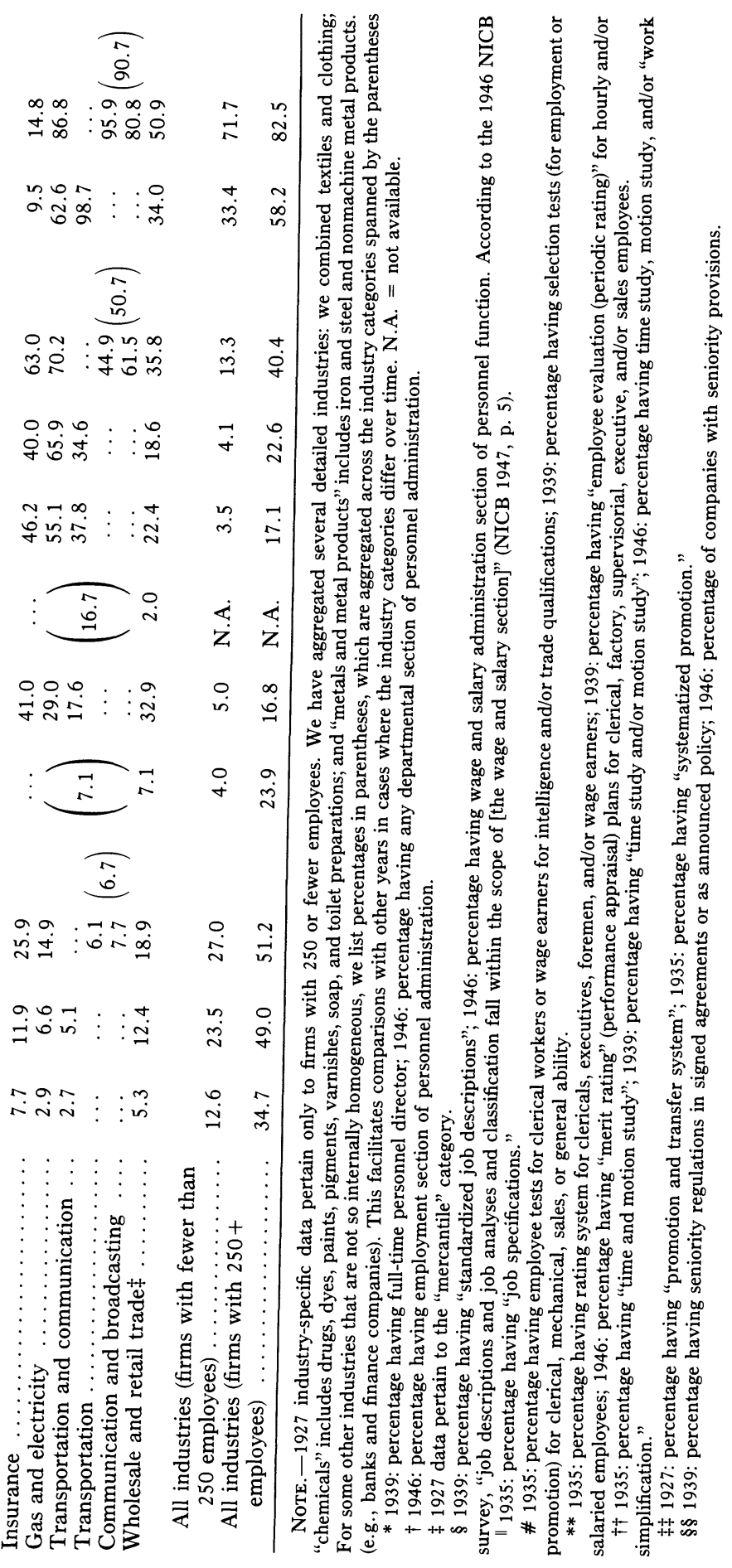


bias. ${ }^{4}$ The NICB members have traditionally had higher response rates than nonmembers, and "in any survey that is conducted solely through correspondence it seems justifiable to assume that it is the more progressive companies that will cooperate" (NICB 1947, p. 3). Yet despite these real and potential biases, the prevalence of the personnel practices that we examine is actually lower than in other surveys conducted during this period, which probably suffered from even more severe response and sample biases. For example, although the mean firm size in the 1935 NICB sample $(1,836)$ was higher than the population mean for establishments, two other surveys done at that time reported mean firm sizes of 2,557 and 4,753 (Pierce School 1935; Parks 1936). In addition, three surveys from the early 1930 s of personnel practices, all more limited in coverage, reported even greater prevalence of personnel departments, job analyses, rating systems, and employment tests than did the 1935 NICB survey, both in the aggregate and for specific industries (Pierce School 1935; Parks 1936; Timmons 1931). For instance, Pierce School (1935) reported that $43 \%$ of the 254 firms surveyed used job analysis, whereas $18 \%$ of firms in the NICB sample reported using job analysis (or $27 \%$ when NICB industry groups are weighted to reflect the industry mix in the Pierce School study). For those few industries represented by a relatively large number of cases in these smaller surveys, estimates of the prevalence of various personnel practices correspond more closely to the NICB data. This, in turn, gives us some confidence in the NICB data.

In short, the NICB surveys apparently provide the most reliable and comprehensive data available on personnel practices in the early decades of this century. One historian of the period refers to the NICB studies as "excellent in every respect, ... . [they] offer the best statistical evidence available on most aspects of welfare capitalism" (Brandes 1976, p. 193), and scholars have recently used these data in charting the spread of personnel departments and internal labor markets (e.g., Jacoby 1983, 1984, 1985; Kochan and Cappelli 1984). Although the samples are perhaps biased toward organizations that were likely to adopt bureaucratic personnel practices, and thus may misrepresent overall levels of usage, they portray employment practices across industries and over time more accurately and in greater detail than other possible data sources.

\section{Personnel Practices Studied}

Three major changes in employment management occurred during the early decades of this century. This first was the introduction of "welfare

\footnotetext{
${ }^{4}$ Response rates were reported only for the 1946 study, when 3,498 of 12,000 companies $(29.2 \%)$ complied with the NICB survey request.
} 
work" practices, with which some firms (e.g., Pullman) were experimenting as early as the 1880s (Slichter 1919). These were the ancestors of modern benefits packages but were considered philanthropic endeavors rather than extensions of employee rights. The second change concerned the increasing specialization and rationalization of work roles occasioned by scientific management. Time and motion studies and job analyses were conducted, job requirements codified, job descriptions introduced, and job training formalized as scientific principles were applied to rationalize the production process itself. The third set of changes involved adopting or extending personnel practices to foster long-term employment and internal labor markets within firms: hiring, promotion, and firing were centralized and regularized; exiting employees were interviewed; systematic turnover records were kept; salary classification, rating systems, and job ladders were introduced or extended; and centralized personnel units flourished (Gordon et al. 1982, p. 189).

This paper focuses on the evolution of the second and third sets of practices, which Edwards (1979) has identified as the underpinnings of "technical" and "bureaucratic" control systems, respectively. Of course, the fact that personnel functionaries in a given company reported the presence of a practice, such as job evaluation, does not tell us about its specific content, scope, or effects. Nonetheless, we believe that these data describing the prevalence of specific personnel practices are invaluable in charting the bureaucratization of employment across industries and over time. First, we briefly summarize temporal and industrial differences in the use of employment practices comprising technical and bureaucratic control systems. We then examine several key sources of change in personnel practice during this period, supplementing our descriptive statistics with relevant historical materials.

\section{RESULTS}

Changes in Personnel Systems, 1927-46

Table 1 shows (by industry and year) the percentage of firms surveyed using selected personnel practices. ${ }^{5}$ Neither the industry categories nor

\footnotetext{
${ }^{5}$ The 1927 data in table 1 pertain only to enterprises with fewer than 250 employees. However, information on a larger sample of companies, including those with 250 or more employees, was available in 1927 for several industrial relations activities (NICB 1928, pp. 68-69). The industry-specific percentages. were generally comparable for both samples, suggesting that the estimates reported for small enterprises in table 1 reasonably represent the prevalence of personnel practices among all business organizations in 1927 . Moreover, $96.5 \%$ of all manufacturing enterprises were in that size range in 1927, although roughly half of manufacturing employment was in organizations with more than 250 employees (NICB 1927, pp. 1-2).
} 
the precise descriptions of every practice studied by the NICB remained identical across surveys (see footnotes to table 1) ${ }^{6}$ Consequently, the rows of table 1 are arranged to facilitate comparisons for a given industrial sector across years, and in some cases percentages have also been aggregated across industrial categories to make such comparisons easier. ${ }^{7}$

Table 1 indicates that by 1935 a number of bureaucratic personnel practices were already widespread in such nonmanufacturing industries as banking, insurance, trade, utilities, and transportation. These industries are often claimed to have followed the lead of innovative manufacturing companies in structuring employment (Baker 1940; Martell 1954). If so, then bureaucratic controls apparently diffused more rapidly in nonmanufacturing industries in this period, since they were more prevalent there by 1935 than in even the most modern manufacturing industries. However, table 1 shows that selected bureaucratic practices were also fairly prevalent by 1935 in modern, mass-production manufacturing industries, particularly electrical manufacturing, automobiles, rubber, and agricultural implements. For instance, at least $40 \%$ of the firms in each of these industries had personnel departments in 1935. These same industries also made the widest use of centralized employment, job analysis, job evaluation, testing, rating systems, rule books, and seniority provisions. In contrast, those practices were much less prevalent in craft industries such as leather, lumber, and printing and publishing, as well as in stone, clay, and glass.

The few manufacturing industries that used bureaucratic practices extensively by 1935 also widely employed time and motion studies, one legacy of Taylorism. Of course, their mass-production technologies were better suited to scientific management (see Bendix 1956, pp. 223-24). Firms in these newer industries may also have adopted modern employment innovations more quickly because they were consistent with notions

\footnotetext{
${ }^{6}$ However, in cases where the definition of an industry or personnel practice changed slightly across surveys, the trends are similar to cases where things remained constant. Thus, results in table 1 are unlikely to be distorted much by definitional changes across surveys.

${ }^{7}$ Certain entries in table 1 pertain to the maximum of multiple values among personnel practices; these are the variables defined (in the notes to table 1) as the percentage of firms in an industry having practice X "and/or" practice Y (e.g., the 1946 measure of rule books). Since the NICB did not publish tables giving industry-specific size distributions, the percentage estimates by size categories are understated slightly for those entries. For instance, in computing the prevalence of rule books in 1946, 38.3\% of firms with 250 or more workers were listed as having employee handbooks and $25.7 \%$ had policy and procedure manuals, so table 1 reports the former figure as the percentage in that size category having "rule books." However, some of the remaining $61.7 \%$ may have had policy and procedure manuals instead, in which case our estimate of the percentage using either practice is too low.
} 
of effective organizing that prevailed at the time of founding (Stinchcombe 1965). Well-documented experiments in scientific management and in sustaining long-term employment at International Harvester, Ford, and elsewhere suggest that firms in these newer industries defined personnel innovation as an integral part of manufacturing innovation.

In sum, these descriptive results are not inconsistent with Edwards's (1979) typology of different control systems, containing distinct sets of personnel activities, and with his classification of economic segments on the basis of their predominant systems of control (simple, technical, bureaucratic). The contemporary differences across industries that he emphasizes are presaged by these data, which describe systems of workplace control in existence a half-century ago. ${ }^{8}$

Between 1935 and 1939 (as between 1927 and 1935), there was little change in the prevalence of most practices listed in table 1 . The use of time and motion studies, however, increased substantially in that period, from $35 \%$ to $49 \%$ of all firms with more than 250 employees. By 1939, seniority provisions were also commonplace in a number of manufacturing industries, stimulated in large measure by passage of the Wagner Act (see section on "Unionization" below).

The most striking findings in table 1 , however, pertain to the period between 1939 and 1946. During World War II, there was a tremendous diffusion of bureaucratic personnel practices. Job evaluation systems, for example, proliferated at a very rapid rate between 1939 and 1946, even in small companies. Table 1 also records sizable wartime increases, especially among larger companies, in the incidence of personnel departments, centralized employment procedures, rating systems (performance appraisals), and seniority provisions. Employment tests spread less quickly during this period, no doubt because employers lowered hiring standards amid increased labor scarcity during the war. Finally, time and motion studies, associated with "technical" control and scientific management, did not proliferate much during the war except for modest increases in several nonmanufacturing industries.

Overall, the evidence in table 1 suggests a wartime diffusion process whereby bureaucratic personnel practices, previously adopted widely in nonmanufacturing and the newer mass-production manufacturing industries that utilized scientific management, spread to other industries. Note that the spread of bureaucratic employment practices between 1939 and 1946 was by no means restricted to industries of strategic importance to the war effort. Table 1 indicates, for instance, that job analysis and

${ }^{8}$ These conclusions (and those that follow in this section) are buttressed by supplemental analyses of the 1935-46 data, including factor and cluster analyses of industries and personnel practices. Detailed results are available on request. 
evaluation, seniority provisions, formalized personnel functions, and service emblems became increasingly commonplace in most industries during World War II, as was true, to a lesser extent, of employment testing and performance rating systems. Later in this paper, we describe the pivotal role of government activities during the war years in bureaucratizing employment, fostering organizational innovations that became institutionalized after the war ended.

\section{Sources of Change in Personnel Systems}

How imperative is imperative? The effects of scale and turnover.-We noted earlier that many efficiency and control theories trace bureaucratic employment practices to scale imperatives and turnover problems confronting employers. In ongoing research, we are assessing how these and other factors shaped personnel activities in different U.S. industries over time. Here, we wish to suggest that the "imperatives" stressed by efficiency and control viewpoints were not all that imperative.

It is certainly true that increasing organizational size favored bureaucratizing employment, reflecting the administrative economies stressed by orthodox perspectives and the "crises of control" emphasized by neoMarxists. The NICB data reveal, for instance, positive associations between average firm size and the prevalence of bureaucratic controls across industries. However, the relationship is far from ironclad. Many firms sampled by the NICB were already very large well before World War II but had not yet adopted bureaucratic practices. For instance, among companies with 5,000 or more employees, $75 \%$ had job evaluation in 1946 versus only $30 \%$ in 1939 , and at least $50 \%$ had some merit rating system, compared with 33\% in 1939 (NICB 1940, p. 47). There is also little evidence directly linking increases in average firm size within industries between 1935 and 1939 to increases in bureaucratic personnel practices in that period (see table 1 and NICB 1936, 1940).

Tolbert and Zucker (1983) have argued that internal organizational imperatives such as size might predict adoption of bureaucratic innovations early in the diffusion process but not after the process is well under way. Table 2 suggests that this pattern pertains to the relationship between firm size and the adoption of employment innovations. The rankorder correlation between average firm size in an industry and the presence of two key bureaucratic controls-specialized personnel units and job evaluation systems-declined considerably in manufacturing between 1935 and $1946 .{ }^{9}$ This decline is consistent with the institutionaliza-

${ }_{9}^{9}$ Table 2 reports rank-order correlations, so estimates of association are unaffected by changes over time in the variances of variables. The table pertains only to manufactur- 
TABLE 2

Spearman Rank-Order Correlations: Average Firm Size and Prevalence of Bureaucratic Personnel Practices, Manufacturing Industries, 1935-46

\begin{tabular}{|c|c|c|c|c|c|}
\hline \multirow{3}{*}{\multicolumn{2}{|c|}{ YEAR }} & \multicolumn{4}{|c|}{ Correlation Based on Average Firm Size IN: } \\
\hline & & \multicolumn{2}{|c|}{ NICB Sample } & \multicolumn{2}{|c|}{ Population } \\
\hline & & $\begin{array}{c}\text { Personnel } \\
\text { Department }\end{array}$ & $\begin{array}{c}\text { Job } \\
\text { Evaluation }\end{array}$ & $\begin{array}{c}\text { Personnel } \\
\text { Department }\end{array}$ & $\begin{array}{c}\text { Job } \\
\text { Evaluation }\end{array}$ \\
\hline 1935 & . & $\begin{array}{l}.67 \\
(19)\end{array}$ & $\begin{array}{l}.60 \\
(19)\end{array}$ & $\begin{array}{l}.48 \\
(15)\end{array}$ & $\begin{array}{l}.41 \\
(15)\end{array}$ \\
\hline 1939 & & $\begin{array}{l}.33 \\
(19)\end{array}$ & $\begin{array}{l}.34 \\
(19)\end{array}$ & $\begin{array}{l}.33 \\
(17)\end{array}$ & $\begin{array}{l}.35 \\
(17)\end{array}$ \\
\hline 1946 & $\ldots$ & N.A. & N.A. & $\begin{array}{l}.21 \\
(16)\end{array}$ & $\begin{array}{l}.08 \\
(16)\end{array}$ \\
\hline
\end{tabular}

Note.-Number in parentheses denotes $N$ of industries. N.A. $=$ not available.

tion process discussed by Toibert and Zucker: "As an increasing number of organizations adopt a program or policy, it becomes progressively institutionclized, or widely understood to be a necessary component of rationalized organizational structure" (1983, p. 35). "Efficiency imperatives" became less imperative as modern personnel administration became standard operating procedure.

Turnover is a second causal imperative emphasized by various perspectives on the employment relation. To be sure, turnover and labor scarcity increased during the war period, when many bureaucratic practices were adopted. Average monthly separation rates across all industries rose from 3.1 per 100 workers in 1939 to a peak of 7.3 in 1943. Quit rates rose from 0.8 to 5.2 per 100 workers during this same period (U.S. Bureau of Labor Statistics 1940, 1943). Table 3 lists turnover rates before and during the war (September 1, 1940, and 1943) for specific industries with data available. The table documents dramatic increases in turnover in this subsample of industries, including several essential to the war effort (e.g., shipbuilding, autos, and aircraft).

In spite of this evidence, however, there are reasons to doubt that bureaucratic controls resulted directly or even principally from turnover per se. Essential industries varied considerably in their turnover rates, yet bureaucratic personnel practices flourished in most of those industries during the war. Moreover, some industries exhibiting the highest rates of turnover were no more likely than average to adopt personnel practices

ing industries, where institutional pressures on organizational structures are less intense than elsewhere in the economy. 
TABLE 3

MONTHLy Separation Rates PER 100 Workers, SELECTED INDUSTRIES: SEPTEMBER 1940, 1943

\begin{tabular}{|c|c|c|}
\hline Industry & 1940 & 1943 \\
\hline Aircraft & 4.12 & 6.91 \\
\hline Auto ... & 2.84 & 7.07 \\
\hline Cotton manufacturing $\ldots \ldots$ & 3.82 & 9.10 \\
\hline Electrical machinery ..... & 2.19 & 7.33 \\
\hline Glass $\ldots \ldots \ldots$ & 1.74 & 9.11 \\
\hline Iron and steel & 1.68 & 5.83 \\
\hline Machinery ... & 2.55 & 6.57 \\
\hline Shipbuilding & 1.53 & 10.42 \\
\hline Silk and rayon & 1.43 & 7.85 \\
\hline All industries* & 3.22 & 6.25 \\
\hline
\end{tabular}

SourCE.-U.S. Bureau of Labor Statistics (1941, p. 169; 1943, p. 1241).

* The figures for all industries pertain to the entire economy, including some industries not listed above.

directly aimed at reducing turnover. Despite high turnover, for instance, firms in shipbuilding and glass apparently did not rely heavily on morale surveys, exit interviews, or service insignias (NICB 1947, p. 32). Rather, as we discuss below, the federal government selectively intervened in certain industries, including shipbuilding, to stabilize employment by mandating or encouraging the adoption of certain bureaucratic practices. In other words, government policies constrained firms' responses to turnover, and the politics of labor mobility, defined largely by the state, may have been more decisive than the economics of mobility during this period. Jacoby (1984) has made a similar point about World War I, namely, that the federal government fostered norms about "acceptable" turnover levels, which were couched in the rhetoric of national security interests.

In sum, organizational scale and turnover were not ineluctable imperatives shaping employment relations. To the extent that new methods of personnel administration were adopted more in large firms and in firms with high turnover, we argue that this was largely because certain institutional pressures favoring adoption were strongest in those settings. We show below how the federal government helped define the "turnover problem," mandating some innovations in the employment relation and selectively encouraging others. We also focus on the role of personnel professionals in fostering bureaucratization during and after World War II. First, however, we briefly summarize what our analyses indicate about unions, another key constituency influencing personnel administration during this period. 
Unionization. - Passage of the Norris-LaGuardia Act (1932), the National Industrial Recovery Act (NIRA; 1933), the Wagner Act (1935), and subsequent legislation encouraged unionization and strengthened unions' impact on the organization of work and employment. Writers of diverse perspectives have argued that employers responded by developing bureaucratic personnel practices to thwart unionization and quell labor unrest. For instance, neo-Marxists, such as Gordon et al. (1982), have recently linked unionization to changes in the employment relationship. In particular, they argue that technical controls used in mass-production industries fueled industrial unionism after passage of the Wagner Act because workers reacted hostilely to those practices. ${ }^{10}$ This prompted management, in turn, to experiment with new bureaucratic techniques that made labor control appear more "natural," impersonal, and in workers' interests (Gordon et al. 1982, chap. 5; Edwards 1979, p. 128). While our aggregated data may obscure the interplay of unionization and changes in the employment relationship, we can investigate some general connections that have been posited between the labor movement and the evolution of personnel practices during this period.

The NICB data are consistent with the claim that scientific management and industrial unionism were linked. There are positive crosssectional relationships between the usage of time and motion studies and the prevalence of CIO unionization across manufacturing industries in 1939 and $1946\left(r_{s}=.43\right.$ and $r_{s}=.26$, respectively). To examine the hypothesized link between technical control and industrial unionism following the Wagner Act, we regressed the percentage of firms in each manufacturing industry reporting CIO agreements in 1939 on the percentage using time and motion studies in 1935. We also controlled for the percentage reporting trade union agreements in 1935, which captures secular trends in unionization across industries. The OLS results in table 4 show that the prevalence of time and motion studies in an industry in 1935 had a sizable positive effect on the percentage of firms organized there by the CIO in 1939, even when prior unionization levels are controlled for. ${ }^{11}$

Unionization also increased during this period in industries where technical controls, such as time and motion studies, were not widely adopted. For example, leather, paper, and glass all registered large increases in

${ }^{10}$ Similarly, Piore (1982, p. 9) argues that "to a very large extent, the practice of American industrial unionism has come to rest upon, indeed to presuppose, Taylorism."

${ }^{11}$ If the 1935 and 1939 disturbances are autocorrelated, then the OLS estimates in table 4 may be biased. Since there is a moderate negative correlation between the two independent variables $(r=-.38)$, table 4 may overstate slightly the effect of 1935 time and motion studies on 1939 CIO unionism (see Hannan and Young 1977, p. 66). 
American Journal of Sociology

TABLE 4

Impact of Technical Control and Unionization in 1935 on Prevalence of CiO UNIONISM: MANUFACTURING INDUSTRIES, 1939 (OLS Estimates)

\begin{tabular}{cccc}
\hline \hline Variable & \multicolumn{1}{c}{ Metric Effect } & $t$ & Standardized Effect \\
\hline Intercept $\ldots \ldots \ldots \ldots \ldots \ldots \ldots \ldots$ & 7.05 & .97 & $\ldots$ \\
1935 time and motion $(\%) \ldots \ldots \ldots$ & .29 & 1.81 & .40 \\
1935 unionization $(\%) \ldots \ldots \ldots \ldots$ & .58 & 2.58 & .58 \\
\hline
\end{tabular}

NoTE.-See text for explanation of variables. $N=19 ; R^{2}=.318 ; \bar{R}^{2}=.233$.

union membership during the 1930s (U.S. Bureau of the Census 1975, p. 177). Welfare work, technical control, and bureaucratic employment practices were less commonplace there than in other industries (NICB 1936, 1940). Instead, "simple control," based on paternalism and occupational traditions, seems to have governed many firms in these craft industries, and increased unionization in the 1930s was not directly attributable to employee reaction against early experiments with scientific management. ${ }^{12}$ Unions in these industries, moreover, were affiliated primarily with the AF of $\mathrm{L}$, rather than with the industrially oriented CIO.

Gordon et al. (1982, pp. 180-82) have also claimed that increasing unionism prompted a period of employer exploration of new bureaucratic control systems in the prewar era. The NICB data suggest that if unionization pressures in the 1930s fueled this exploration, employers' responses were neither immediate nor uniform. Although table 1 documents some increases among manufacturing firms in the prevalence of selected bureaucratic personnel practices by 1939 (compared with the years before the Wagner Act), there is little evidence of an immediate or widespread bureaucratization of employment in response to increased unionization activity in the 1930s. For instance, in those sectors with a high percentage of firms using time and motion studies (e.g., autos, electrical manufacturing, rubber)-industries where worker hostility was supposedly most intense-there were no large increases between 1935 and 1939 in the prevalence of such bureaucratic controls as personnel departments, employment and promotion testing, job analysis and evaluation, and rating systems (see table 1$).{ }^{13}$ This suggests either that any "threat" effects

${ }^{12}$ It is likely, e.g., that hardships experienced by laborers in the Depression and the impetus of labor legislation, which cut across all industries, contributed to the organization of craft workers in this period (Bernstein 1970, p. 218).

${ }^{13}$ In fact, some industries actually exhibit small declines in the prevalence of some practices during this period, although this is probably due to sampling error and an imperfect correspondence between the measures of some practices in 1935 and 1939 (see notes to table 1). 
of unionization pressures occurred earlier or else that employers' responses to the labor movement were indeed so exploratory at this point that there was no conspicuous trend within and across industries by 1939 .

Unionization apparently did have a rapid and pervasive effect on the employment relationship by diffusing seniority provisions through written agreements in unionized enterprises or announced policy in other settings. According to table 1, over $80 \%$ of firms sampled in the auto industry, $79 \%$ in agricultural implements, $70 \%$ in electrical manufacturing, and $63 \%$ in rubber had seniority provisions in place by 1939 . These same industries were also heavily organized by the CIO during the preceding period (Bernstein 1970; Fine 1969). Not surprisingly, there is a strong relationship between the prevalence of these seniority provisions (either in written agreements or as announced corporate policy) and industrial unionism in $1939\left(r_{s}=.55\right.$ in all industries and .45 in manufacturing). ${ }^{14}$

Unfortunately, the NICB data do not provide information on seniority arrangements before 1939 in order to assess their growth in the wake of the Wagner Act and similar legislation. However, the historical literature of this period underscores the stake that labor and management perceived that they had in developing seniority-related policies in response to that pro-union legislation. Industrial labor wanted formalized promotion policies that used seniority as the sole basis of advancement to protect against retaliation for affiliating with unions or against the biases of company foremen (Harbison 1939, p. 32; 1941, p. 37). Management wished to retain control over hiring, promotions, and firing but recognized the need to negotiate with labor. Managers therefore sought to draft seniority policies that also included loyalty and ability as requirements, thereby preserving discretion over employment (Bernstein 1970, pp. 46468, 792; Stone 1974, p. 113). As a result, policies establishing seniority rights spread to many firms, even though their specific contents varied (Fine 1969, pp. 181, 324).

World War II increased this process of negotiation and adjustment between labor and management. The government pressured unions to maintain domestic peace, and unions informally agreed to limit work stoppages, allowing the National War Labor Board to arbitrate unionmanagement conflicts (Bernstein 1970, p. 729; Sweeney 1956, pp. 52-58).

${ }^{14}$ Unionization during this period also fostered several other specific personnel practices, particularly the use of industrywide comparisons for job rates (NICB 1940, p. 20). Unions had long complained about wage differences among companies and regions for jobs that were essentially the same. In steel and auto, union agreements with the leading firms established benchmarks for negotiations with smaller organizations (Bernstein 1970, pp. 481, 553; Fine 1969, p. 329). 
Moreover, specialized personnel subunits devoted to maintaining harmonious labor relations flourished during the war in such highly unionized sectors as communications, transportation, utilities, shipbuilding, petroleum, aircraft, rubber, and autos (see NICB 1947, p. 16; Kochan and Cappelli 1984). Unions in essential war industries therefore were more receptive to some personnel innovations instituted by firms and by the state to regulate the wartime economy than they had been before the war.

There was less accommodation on the part of AF of $\mathrm{L}$ unions to employers' use of modern personnel practices. Many AF of L unions had resisted earlier efforts at technical control, which were perceived as weakening craftworkers' discretion over their trades (see Stark 1980). ${ }^{15}$ Industries organized along AF of $\mathrm{L}$ lines also appear less likely to have explored the newer bureaucratic controls that diffused widely elsewhere by the end of World War II. For instance, the prevalence of job evaluation systems in 1946 was inversely related to the degree of AF of L presence in manufacturing industries $\left(r_{s}=-.54\right)$. Manufacturing industries with a strong AF of $\mathrm{L}$ presence were also significantly less likely to exhibit widespread usage of personnel departments even as late as 1946 $\left(r_{s}=-.34\right)$.

In sum, our analyses provide some support for theoretical perspectives that link unionization with the evolution of technical and bureaucratic control in U.S. industry. However, it is clearly difficult to determine from these data whether industrial unions were "co-opted" by management's experiments in personnel administration or to estimate precisely the magnitude of unions' influence on changes in the employment relationship during this period. As we have seen, management sometimes adopted and extended specialized personnel activities even in the absence of unions or proximate union threats, especially in the nonmanufacturing sector (see, e.g., banking, insurance, and trade in table 1). Also, unions genuinely perceived many of these innovations to be beneficial. The same seniority systems that provided firms with convenient bases for administering rewards also protected industrial workers from layoffs and capricious treatment. Thus, unions and bureaucratic arrangements may have been complementary means of controlling workers in many instances (particularly in CIO industries), rather than alternatives, as Pfeffer and Cohen (1984) have suggested. Increased accommodation between labor and management during this period aided the diffusion of modern person-

\footnotetext{
${ }^{15}$ In 1939 and 1946, the percentage of firms with AF of L agreements was negatively correlated with the prevalence of time and motion studies (for 1939, $r_{s}=-.31$ for manufacturing and $r_{s}=-.24$ for all industries; for 1946, the correlations are -.75 and -.20 , respectively).
} 
nel innovations. This accommodation was largely due to a unique stimulus that has been underemphasized in recent discussions of bureaucratic control: World War II and the government intervention that it occasioned.

The federal government and World War II.-World War II brought greater federal intervention in labor relations and employment than ever before. The War Production Board (WPB), War Labor Board (WLB), and War Manpower Commission (WMC) engaged in unprecedented government manipulation of labor markets, union activities, and personnel practices. These interventions had two overlapping effects. First, government often mandated general models or requirements for bureaucratizing employment. For example, early WPB policies sought to reduce turnover and wage competition by standardizing employment conditions in volatile industries such as shipbuilding. Here the government helped develop and diffuse specific models of personnel management. Second, in many cases, government interventions encouraged firms to adopt their own particular bureaucratic controls. For instance, later WPB policies involved regional employment stabilization plans to control turnover and wages. In effect, these plans encouraged firms to expand personnel functions in order to document their labor needs vis-à-vis other firms and industries. In this section, we document how government interventions fueled the development of bureaucratic controls by creating models of employment and incentives to formalize and expand personnel functions.

An employment-stabilization plan introduced in shipbuilding in 1941 illustrates how the state attempted to limit competition among firms for employees, which had been producing high turnover and wage inflation, by developing a bureaucratic model of personnel relations for an entire industry. In southern California, the creation of large shipbuilding and aerospace industries within the same labor market wreaked havoc on both industries (Gray 1943, p. 7). In April 1941, the National Defense Advisory Committee, predecessor of the WLB, organized a conference of management and labor representatives from the Pacific shipbuilding industry. Guidelines concerning wages, hours, shift work, strike avoidance, and apprentice training were adopted (U.S. Bureau of Labor Statistics 1941, p. 1162). These guidelines effectively standardized industry work arrangements and working conditions to prevent "pirating" of workers. Similarly, in June 1942, the building trades unions agreed to a WLB proposal to stabilize wage rates on all federal projects. Though less complex, this agreement had the same effect as the shipbuilding stabilization plan: drastically reducing turnover and wage competition by creating a standard model of employment relations within the industry. Jacoby has suggested that governmental intervention during World War I had a similar effect (1985, pp. 140-47). 
Later, WPB employment-stabilization efforts followed a different pattern; stabilization plans in lumber and nonferrous metals mining, for instance, controlled labor mobility directly. In contrast to the shipbuilding controls, which limited competition among employers, these new plans limited employee mobility. Like the shipbuilding industry, lumber and nonferrous mining companies faced increased wartime demand accompanied by labor shortages and rising turnover, and these trends in product and labor markets made government intervention both more necessary and more palatable (U.S. Bureau of Labor Statistics 1942, p. 713). The U.S. Employment Service, then under WPB control, required that a worker departing from a job have a certificate of separation to work elsewhere. This document certified that the separation was in the "best interests of the war effort" (U.S. Bureau of Labor Statistics 1942, p. 235). Likewise, employers could dismiss workers only for gross misconduct. Male employees leaving jobs without authorization were subject to immediate reclassification by the Selective Service into an active-duty category and then drafted.

This system was later extended to control regional labor markets across other industries. By November 1943, the WMC had implemented 78 local employment-stabilization plans in areas with labor shortages, following the same certification guidelines discussed above. Further, in mid1944, the WPB established an employment-ceiling program whereby regional manpower directors set "the maximum number of . . . specified types of employees which an establishment may have in its employ during a specified period" (U.S. Bureau of Labor Statistics 1944, p. 749). Lowpriority industries, such as retail trade, were forced to release workers (U.S. Bureau of Labor Statistics 1945, p. 535), while high-priority industries, such as aircraft, were allocated more positions. Meanwhile, Employment Service procedures for referring in-migrants were tightened to prevent those leaving shortage areas from obtaining employment in nonshortage areas. In this way, the "certificate of availability" program was nationalized, and employers had to justify their labor needs not only visà-vis other local employers but in relation to all U.S. industry. The Selective Service also aided in labor market manipulation by changing the draft deferment status of positions as staffing shortages changed. Workers in nonessential industries and occupations often had to choose between finding jobs in more essential settings and going to war (U.S. Bureau of Labor Statistics 1943, p. 468).

Firms were therefore compelled to initiate or expand personnel departments to document their needs. Because employers had to classify jobs by skill and wage categories to satisfy the new national stabilization plans, job analysis and evaluation flourished (Walters 1945, pp. 10-11), as documented in table 1. The government also required firms to file "manning 
tables" detailing skill and manpower needs and encouraged them to enumerate jobs in terms of new Dictionary of Occupational Titles (DOT) guidelines (U.S. Bureau of Labor Statistics 1945, pp. 419-20). Thus, the government encouraged the formalization of work roles and the diffusion of standard job definitions across firms by providing employers with a free and easily accessible job-analysis system. Other reporting requirements necessitated employment and turnover records, rating and salary classification systems, and promotion paths reflecting skill gradients among jobs-all designed to aid the war effort by ensuring maximum utilization of human resources within and among firms. Companies without competent personnel departments were hard-pressed to justify their staffing requirements, and firms that had not previously done so moved quickly to implement or augment personnel departments, job analysis and evaluation systems, wage surveys, and manpower analyses to substantiate their labor needs.

Federal hiring controls, combined with high turnover rates, also fostered efforts to lengthen employment relationships. Seniority provisions, exit interviews, stabilization plans, turnover records, and service emblems were increasingly adopted, all designed to reduce exits and bind workers to firms. For instance, between 1939 and 1946, the existence of seniority provisions increased from $58 \%$ to $83 \%$ in companies with 250 or more employees in a period of full employment, and the use of service emblems increased from $23 \%$ to $40 \%$ in the same firms (see table 1). These practices were clearly adopted to maintain worker loyalty.

Several other government programs fostered additional personnel practices. The Fair Labor Standards Act of 1942 required firms to record wages and hours for every employee (Jacoby 1984, p. 53). In the Basic Guide for Labor-Management Committees (WPB 1945a), labormanagement committees and personnel departments were encouraged to study absenteeism and turnover and to institute exit interviews, training programs, and safety programs. Through its training efforts, the WPB developed manuals on job instruction and promoted job analysis (WPB 1942 , sec. 2). It also actively encouraged wage incentive plans (WPB 1945b) and suggestion systems (WPB 1943), further increasing the size and duties of personnel departments.

The War Labor Board was another important source of models for personnel management. It ruled on numerous grievances brought by labor unions during the war, and its decisions established precedents that set the standards for labor-management relations. Thus, the board's rulings and solutions spread quickly across industries. In many instances, the WLB initiated solutions to problems that had long preceded the war. In iron and steel, for example, a resurgence of unionization after 1937 significantly increased the number of grievances concerning wage ineq- 
uities, which were not arbitrable under prevailing steel agreements. Management too was dissatisfied with the unsystematic administration of wage policies in the industry. Thus, both parties had an interest in systematizing and formalizing jobs and rewards, but little progress had been made. The WLB served as a major impetus for change. Workers' grievances were referred to that agency during the war, and labor and management were ordered to eliminate wage inequities within plants. At the same time, various companies organized the Cooperative Wage Survey during the war to develop proposals for job evaluation and systematic wage administration in iron and steel. The bulk of this plan was incorporated into bargaining agreements made after the war. Some inequities were eliminated, but many other discrepancies in wages and incentive pay were institutionalized (Elbaum 1984; Steiber 1959).

In short, the war occasioned cooperative arrangements among steel companies, under pressure from the WLB, which served as catalysts for the 1947 job evaluation system. These agreements, which were industrywide and uniformly applied, institutionalized historical distinctions among jobs and framed the contemporary reward system in the industry. Labor viewed the new system as consistent with their aim of eradicating capricious wage differentials, while steel companies saw the changes as systematizing and streamlining employment practices.

According to one wartime study, the same process occurred in southern California's aircraft industry (Gray 1943). Wartime demand encouraged the standardization of aircraft work, which reduced training requirements. Consequently, new workers resented the higher pay of senior workers because the former perceived no relationship between seniority and levels of performance. Conversely, some older workers entering the industry to replace draftees resented higher earnings among younger (but more experienced) employees. Workers were thus interested in seeing job requirements and rewards rationalized. Management was also clearly interested in systematizing personnel practices across firms during the war because consistent policies would reduce competition from other local firms and offset differences among the various unions representing employees of the major defense contractors. In addition, the aircraft companies quickly recognized the longer-term benefits of these changes in personnel administration: streamlining and standardizing job definitions; reducing duplication and facilitating wage surveys; centralizing employment procedures and aiding in securing workers from the Employment Service, who used the same DOT categories to classify jobs as did the aircraft companies; and assisting in training by improving information on job requirements (Gray 1943, pp. 18-20).

Consequently, unions and management complied with a 1943 WLB order for job evaluation and wage systematization in the local aircraft 
industry. One union chairman promoted the plan to his constituents as follows: "The purpose of the plan is to obtain a better relation of rate to job. . . [ [It $]$ is not to lower rates of certain employees. Those who are now being paid rates that are out of line because they are too high can be transferred to work which has a higher value. Those who are now underpaid will be classified upwards. In an industry that is growing like aircraft, constantly improving its methods of production in order to turn out more planes for national defense, job evaluation is never completed" (cited in Gray 1943, pp. 75-76). This quotation illustrates how World War II created a transcendent, extraorganizational interest that overrode potential conflicts between labor and management. (It has also been suggested that unions looked favorably on job evaluation because, with wage levels frozen, job reclassification was often the only way for workers to secure pay increases.) Both parties perceived benefits to be had by accepting bureaucratic controls mandated directly or indirectly by the state. The costs were accepted as regrettable but inevitable concomitants of the war effort. To be sure, the labor shortages and high product demand created by the war made governmental intervention not only necessary but also more acceptable to all concerned.

In sum, federal activities during the war fostered bureaucratization of employment in two ways. First, early employment-stabilization plans, WLB rulings, and WPB publications provided models of employment practices that often extended to entire industries or sets of industries, thereby encouraging isomorphism among firms. Second, regional stabilization plans, Selective Service activities, the new DOT, and the government-led movement to reduce turnover provided strong incentives for firms to establish or extend personnel departments that could analyze and justify labor needs and institute bureaucratic mechanisms to reduce turnover. The bureaucratization of employment during this period may, as Bendix (1956, chap. 3) has argued, reflect a broader process of societal rationalization accompanying the advent of large-scale economic enterprise. However, we believe that the tendency for bureaucratic controls to arise first in large firms (and those with high turnover) had a great deal to do with the fact that these organizations were most visible to government agencies monitoring manpower developments during World War II. Afterward, labor, management, and government discovered new interests that were served by many arrangements and practices that had developed during the war. These innovations became institutionalized and gradually diffused to other firms and industries, owing largely to the activities of personnel professionals.

The personnel profession and the postwar period.-Gordon et al. (1982), Edwards (1979), and others have characterized the period from the end of World War II to the mid-1970s as one of "consolidation," in 
which earlier labor-management conflicts were supplanted by mutual accommodation to new bureaucratic control systems. The role of personnel administrators in this process of consolidation is documented in the postwar literature on personnel management (also see Harris 1982, chap. 6). At first, there was fear among personnel managers that their departments would be dismantled after the armistice, as had happened after World War I. For example, a 1946 NICB report surveyed the organization of personnel functions in 10 model companies, stating that "war industries were purposely avoided [in the report] . . . those in which large personnel organizations had sprung into being overnight and which might be reduced as suddenly with the anticipated cutback of employment at the conclusion of the war" (NICB 1946b, pp. 5-6; see also Kushnick 1944, p. 6; Silberman 1983, pp. 59-67).

Consequently, discussions of the "reconversion of personnel" began appearing in such practitioner-oriented journals as Personnel Administration and Personnel Journal even before the end of the war (e.g., Fredenburgh 1944; Kirkpatrick 1945b; Kushnick 1945). Personnel specialists seized on particular problems associated with the conversion to a peacetime economy, such as the physical and mental disabilities of returning veterans. Furthermore, labor surpluses intensified the importance of choosing qualified individuals from the large pool of workers available for a limited number of jobs. Personnel administrators therefore emphasized their past and present expertise in developing selection and evaluation procedures (Hayes 1945; McQuitty 1947; Zerba 1945, p. 115).

Reconversion problems would not last forever, however, and personnel functionaries sought a more permanent justification of their role. They emphasized two themes: productivity and labor relations. After the war, veterans preference policies and built-in wage increases negotiated by unions during wartime required management to pay higher wages without regard to labor's productivity. At the same time, many companies experienced lower postwar sales owing to declining U.S. demand for durables. Many companies therefore sought to tie wages directly to productivity, keeping the level of demand high through foreign trade (NICB 1946a). Personnel managers were quick to claim sole expertise in measuring productivity and in determining appropriate rewards through job classification and evaluation as well as worker testing and rating procedures (Kirkpatrick 1945a; Tyerman 1945, p. 78; Wallace 1946, pp. 1820).

Labor relations also were of paramount concern immediately after the war. Manpower surpluses and decreased demand for durables threatened labor's ability to negotiate wage and benefit increases. Moreover, veterans preference programs created conflicts within firms that required labor-management arbitration. Management saw these difficulties as a 
way to regain some of the control lost in the late thirties and during the war (e.g., Sweeney 1956, pp. 62-68; Harris 1982). Many companies established new wage and hiring policies; not surprisingly, unions resisted. Strike activity increased far above wartime levels, with the number of man-days idle tripling from 1945 to 1946 (U.S. Bureau of Labor Statistics 1947, table E-1). The federal government intervened in 1947 by passing the Taft-Hartley Act, which eliminated some union prerogatives, but firms were still under strong pressure to negotiate with labor. Numerous articles appeared in the personnel journals at this time discussing ways to present worker grievances to management, and personnel managers were touted as intermediaries in labor-management negotiations (Ashivin 1946, pp. 233-38; Jones 1945; Scott, Deadrick, and Taylor 1983; Kochan and Cappelli 1984).

Personnel workers also sought to strengthen their positions by forging a stronger professional identity, as they had tried to do earlier in the century (Jacoby 1985, chap. 4). Again, the applied literature on personnel administration highlights this trend. Several periodicals devoted increased attention to the requirements for creating a profession (e.g., National Roster of Scientific and Specialized Personnel 1946; vols. 27-28 of Personnel Journal; vol. 8 of Personnel Administration). In addition to discussing professional education and credentialing procedures, these journals covered meetings of personnel associations and encouraged debate and communication in an evolving professional network. For example, Personnel Administration reported the activities of the Society of Personnel Administration. The society, founded in 1937 by 17 members of the federal Civil Service, had already grown to more than 650 members by 1945 and to more than 1,850 members by 1951 (Carlson 1945, p. 19; Goode 1951, p. 58).

As personnel work became professionalized and personnel practices were institutionalized, the profession grew rapidly. The number of personnel and labor relations professionals in the United States increased from fewer than 30,000 in 1946 to 53,000 in 1950 and 93,000 in 1960; in comparison, the professional work force as a whole increased from $3,879,000$ in 1940 to about $5,000,000$ in 1950 to $7,336,000$ in 1960 (U.S. Bureau of Labor Statistics 1949, p. 107; U.S. Bureau of the Census 1975, pp. 140-41). Thus, in percentage terms, the growth rate of the personnel profession far outstripped the growth rate of other professions (and of the U.S. labor force as a whole) during the postwar years.

Once adopted, bureaucratic employment practices survived despite environmental changes, which is consistent with theories of organizational inertia (Stinchcombe 1965; Hannan and Freeman 1984). They also served as models for new or peripheral firms in an industry that were entreated through publications such as those of the NICB to adopt these state-of- 
the-art practices. Some evidence of the inertia of bureaucratic personnel practices, albeit from an earlier period, is provided by the 1935 NICB survey, which asked firms about active and recently discontinued personnel activities. The two sections of table 5 summarize some illustrative data from this survey. Organizations frequently abandoned various welfare and benefit programs in response to the Depression (upper section). However, as Brody (1980, chap. 2) has noted, efforts to systematize and regularize employment activities were rarely abandoned (lower section). ${ }^{16}$ Similarly, 1953 NICB data suggest that such innovations as personnel departments, salary classification systems, merit rating plans, and exit interviews all persisted, diffusing from larger to smaller companies after the war (NICB 1954). For example, 79\% of the firms surveyed across all industries in 1953 reported having a central personnel department, compared with $63 \%$ in 1946, and among firms with 250 or fewer employees $45 \%$ had personnel departments in 1953 , compared with $30 \%$ seven years earlier. Merit rating plans also became more popular, increasing from $28 \%$ in 1946 across all industries to $45 \%$ in 1953 and from $20 \%$ to $30 \%$ among companies with fewer than 250 employees.

Thus, despite changing environmental circumstances, bureaucratic controls over employment persisted and spread. Obviously, there were also important continuities in firms' environments favoring the retention of these personnel innovations. In particular, various government reporting requirements and programs established earlier remained in placeincluding unemployment insurance, safety regulations, and pension programs-necessitating ongoing data collection and research efforts by personnel specialists. These governmental activities also established precedents for subsequent state interventions into employment matters such as the safety, social welfare, civil rights, and affirmative action programs of the last three decades, extending further the territory of personnel specialists.

Of course, it is difficult to know how successful personnel specialists were in their postwar efforts to secure organizational power and gain legitimacy in the eyes of management (see Silberman 1983). The rapid growth and professionalization of personnel work may reflect the success of personnel functionaries in applying long-standing solutions to everchanging problems, as illustrated by the persistence of bureaucratic employment practices that we documented above and by the recent revival of such techniques as job evaluation to effect pay equity. Some investigators may have interpreted the flurry of personnel activity and professional

${ }^{16}$ A survey of somewhat larger companies in Ohio between 1929 and 1936 revealed similar results (although welfare practices were dropped less frequently among these larger corporations), concluding that the new "personnel methods and plans . . . seem to have stood the test of the depression" (Parks 1936, p. 39). 
TABLE 5

Adoption and Discontinuation of Various Personnel Benefits AND PRograms, $1935(\%)$

\begin{tabular}{|c|c|c|}
\hline & $\begin{array}{c}\% \text { of Firms with } \\
\text { Program }(N=2,452)\end{array}$ & Programs Discontinued* \\
\hline \multicolumn{3}{|l|}{ Benefit programs: } \\
\hline Bonus, attendance $\ldots \ldots \ldots \ldots$ & 2.9 & 108.3 \\
\hline Bonus, service $\ldots \ldots \ldots \ldots \ldots$ & 7.3 & 40.8 \\
\hline Profit sharing $\ldots \ldots \ldots \ldots \ldots \ldots$ & 4.7 & 48.3 \\
\hline Suggestion system $\ldots \ldots \ldots \ldots \ldots$ & 23.1 & 28.1 \\
\hline Savings plan $\ldots \ldots \ldots \ldots \ldots$ & 15.8 & 16.3 \\
\hline Employee magazine $\ldots \ldots \ldots \ldots$ & 14.2 & 68.3 \\
\hline Cafeteria/restaurant $\ldots \ldots \ldots \ldots$ & 28.3 & 15.6 \\
\hline Athletic program $\ldots \ldots \ldots \ldots \ldots$ & 47.1 & 25.0 \\
\hline Picnics or outings $\ldots \ldots \ldots \ldots \ldots$ & 33.3 & 23.9 \\
\hline Christmas gifts $\ldots \ldots \ldots \ldots \ldots$ & 19.8 & 39.4 \\
\hline Dances $\ldots \ldots \ldots \ldots \ldots \ldots \ldots$ & 21.1 & 15.6 \\
\hline \multicolumn{3}{|l|}{ Programs systematizing employment: } \\
\hline Centralized employment $\ldots \ldots \ldots$ & 41.2 & 1.4 \\
\hline Turnover records $\ldots \ldots \ldots \ldots$ & 38.2 & 4.1 \\
\hline Layoff procedure $\ldots \ldots \ldots \ldots \ldots$ & 20.8 & .8 \\
\hline Maximum hiring age $\ldots \ldots \ldots \ldots$ & 11.1 & 2.6 \\
\hline Personnel department $\ldots \ldots \ldots \ldots$ & 32.4 & 3.4 \\
\hline Employment records $\ldots \ldots \ldots \ldots$ & 55.5 & .4 \\
\hline Rule books $\ldots \ldots \ldots \ldots \ldots \ldots$ & 19.8 & 6.4 \\
\hline Job analysis & 17.7 & 3.2 \\
\hline Job specification ... & 13.2 & 2.5 \\
\hline Systematic promotion $\ldots \ldots \ldots \ldots$ & 12.8 & 1.3 \\
\hline Salary classification $\ldots \ldots \ldots \ldots$ & 14.1 & 1.7 \\
\hline Rating system $\ldots \ldots \ldots \ldots \ldots$ & 14.8 & .0 \\
\hline Employment tests $\ldots \ldots \ldots \ldots \ldots$ & 7.3 & .0 \\
\hline Time and motion study $\ldots \ldots \ldots$ & 27.3 & 4.8 \\
\hline
\end{tabular}

SoURCE.-NICB (1936, chap. 2).

* Entries reflect programs discontinued since 1927 as a percentage of active programs in 1935 .

identity crises after World War II as signals indicating the birth of "bureaucratic control" (e.g., Gordon et al. 1982). In contrast, our analyses suggest that the new system of control was well in place by the end of the war and that personnel workers had strong organizational and professional interests in redefining, extending, and calling greater attention to their activities in the postwar era.

\section{SUMMARY AND CONCLUSIONS}

Students of labor markets and of organizations share an interest in the origins of bureaucratic employment practices. Most accounts of bureau- 
cratization point to either efficiency or control functions served by formal personnel structures. Indeed, we have summarized some evidence consistent with those theories. For instance, differences across industries in firm size and turnover rates are associated with differences in personnel practices, as are rates of unionization. In our view, however, both efficiency and control arguments are limited in accounting for the evolution and diffusion of modern employment relations. Our analyses highlight the importance of government intervention in that process during World War II, a factor usually treated primarily as a residual. Our conclusions are consistent with a study of recent practices by Dobbin et al. (in press), which finds that the organizations that are most progressive in creating affirmative action programs and grievance systems are the ones receiving the most scrutiny from the state. As it did during World War II, government intervention has wrought fundamental changes in contemporary human resource management. The state has repeatedly established the boundaries within which managerial imperatives, whether of efficiency or social control, shape employment and opportunity (see Burawoy 1983). Stark has made a similar argument about state intervention during World War I, claiming that it "created the market conditions in which capitalists could adopt many of the schemes of the scientific management movement" (1980, p. 110, emphasis added).

To be sure, the rudiments of bureaucratic control were already established early in the 20th century (Jacoby 1985). However, we have argued that government agencies fostered a widespread diffusion of personnel innovations during World War II by mandating specific models of employment, by providing incentives for organizations to create or expand personnel departments and bureaucratic controls, and by providing a set of overarching interests that prompted labor-management accommodation. After the war, these personnel innovations were used in the pursuit of other interests by labor and management. Also, organizational inertia and the professionalization of personnel administration institutionalized many bureaucratic controls in peacetime that had proliferated before and during the war.

Our results have several implications for organizational theory. For instance, they inspire conjectures about the role of crises in institutional change. In periods of crises, such as wars, stable institutions are susceptible to revolutionary change. In a sense, crises recreate some "liabilities of newness," encouraging managers to catch up with modern organizing techniques and reorient their organizations (Stinchcombe 1965). New solutions, in turn, develop their own inertia until challenged by future crises (Krasner 1984).

Our findings are also consistent with the predictions of institutionaliza- 
tion theorists about how and where bureaucratic innovations diffuse. The evidence presented here supports Tolbert and Zucker's (1983) thesis that the spread of new organizational practices is strongly linked to internal functional requirements only in the earlier stages of diffusion. Between 1939 and 1946, bureaucratic personnel practices spread from newer, high-turnover industries with larger firms (such as auto and rubber) to older, more stable industries with smaller firms (such as leather and lumber). To some extent, this process of diffusion was under way even before the war: bureaucratic controls had already spread from early manufacturing innovators - typically, large firms with high turnover-to banking, insurance, and other nonmanufacturing sectors, which traditionally had lower rates of turnover and smaller organizational units (see Piore 1983, p. 33). Thus, government intervention during wartime may have merely hastened trends to the bureaucratization of employment. This early and rapid diffusion of bureaucratic controls to nonmanufacturing organizations may reflect the fact that, as institutional theorists note, legitimacy in such settings often depends on adopting procedures that instill confidence and establish continuity and the semblance of rationality (Meyer and Rowan 1977; DiMaggio and Powell 1983).

By diffusing state-of-the-art personnel practices throughout the economy, government agencies, unions, and personnel professionals have attenuated (or at least complicated) the impact of organization-level characteristics on the employment relationship. That is, bureaucratic controls have diffused across organizations that differ in age, size, technology, and other dimensions that are frequently claimed to affect personnel practices. The state, unions, and personnel professionals are important sources of equifinality in organizational arrangements, prompting very different enterprises to exhibit similar employment relations.

We do not mean to imply that such firm-level considerations as scale, turnover, and labor unrest were unimportant in shaping modern personnel systems; indeed, we have alluded to their effects throughout. Nor do we wish to suggest that management and labor were thoroughly passive recipients of edicts from above. We do, however, take issue with perspectives that trace changes in the employment relationship to ineluctable imperatives shaping organizational behavior, whether those perspectives refer to surplus-expropriating capitalists, profit-maximizing managers, or utility-maximizing laborers. Such accounts are reductionistic and overly simplistic. By sanctioning modern employment practices and by encouraging the diffusion of those practices throughout the economy, the state has played a major role in the spread of bureaucratic control and internal labor markets. 


\section{REFERENCES}

Ashivin, Barnard C. 1946. "Labor Relations Control." Personnel Journal 24 (9): 322 29.

Baker, Helen. 1940. Current Policies in Personnel Relations in Banks. Princeton, N.J.: Princeton University, Industrial Relations Section.

Bendix, Reinhard. 1956. Work and Authority in Industry. New York: Wiley.

Bernstein, Irving. 1960. The Lean Years: A History of the American Worker, 19201933. Boston: Houghton Mifflin.

. 1970. The Turbulent Years: A History of the American Worker, 1933-1941. Boston: Houghton Mifflin.

Blau, Peter M., and Richard A. Schoenherr. 1971. The Structure of Organizations. New York: Basic.

Brandes, Stuart D. 1976. American Welfare Capitalism, 1880-1940. 2d ed. Chicago: University of Chicago Press.

Brody, David. 1980. Workers in Industrial America. New York: Oxford University Press.

Burawoy, Michael. 1983. "Between the Labor Process and the State: The Changing Face of Factory Regimes under Advanced Capitalism." American Sociological Review 48:587-605.

Carlson, Dick. 1945. "Annual Report of the President." Personnel Administration 7 (10): 18-19.

Clawson, Dan. 1980. Bureaucracy and the Labor Process. New York: Monthly Review Press.

DiMaggio, Paul, and Walter W. Powell. 1983. "The Iron Cage Revisited: Institutional Isomorphism and Collective Rationality in Organizational Fields." American Sociological Review 48:147-60.

Dobbin, Frank R., Lauren Edelman, John W. Meyer, W. Richard Scott, and Ann Swidler. In press. "The Expansion of Due Process in Organizations." In Institutional Patterns and Organizations: Culture and Environment, edited by Lynne G. Zucker. Boston: Pitman.

Doeringer, Peter B., and Michael J. Piore. 1971. Internal Labor Markets and Manpower Analysis. Lexington, Mass.: Heath.

Edwards, Richard. 1979. Contested Terrain. New York: Basic.

Elbaum, Bernard. 1984. "The Making and Shaping of Job and Pay Structures in the Iron and Steel Industry." Pp. 71-108 in Internal Labor Markets, edited by Paul Osterman. Cambridge, Mass.: MIT Press.

Fine S. 1969. Sit-Down: The General Motors Strike of 1936-1937. Ann Arbor: University of Michigan Press.

Fredenburgh, Franz A. 1944. "Reconversion of Personnel." Personnel Journal 23:242-54.

Goode, Cecil E. 1951. "Advancing Personnel Management through Our Society." Personnel Administration 14 (4): 58-75.

Gordon, David M., Richard Edwards, and Michael Reich. 1982. Segmented Work, Divided Workers. London: Cambridge University Press.

Granovetter, Mark S. 1984. "Small Is Bountiful: Labor Markets and Establishment Size." American Sociological Review 49:323-34.

Gray, Robert D. 1943. Systematic Wage Administration in the Southern California Aircraft Industry. Industrial Relations Monograph no. 7. New York: Industrial Relations Counselors.

Hannan, Michael T. 1971. Aggregation and Disaggregation in Sociology. Lexington, Mass.: Heath.

Hannan, Michael T., and John Freeman. 1984. "Structural Inertia and Organizational Change." American Sociological Review 49:149-64. 
Hannan, Michael T., and Alice A. Young. 1977. "Estimation in Panel Models: Results on Pooling Cross-Sections and Time Series." Pp. 52-83 in Sociological Methodology, edited by David R. Heise. San Francisco: Jossey-Bass.

Harbison, Frederick. 1939. The Seniority Principle in Union-Management Relations. Report no. 57. Princeton, N.J.: Princeton University, Industrial Relations Section.

- 1941. Seniority Policies and Procedures as Developed through Collective Bargaining. Report no. 63. Princeton, N.J.: Princeton University, Industrial Relations Section.

Harris, Howell J. 1982. The Right to Manage. Madison: University of Wisconsin Press.

Hayes, Elinor. 1945. "New Uses of Personnel Research." Personnel Administration 8 (2): $5-10$.

Hodson, Randy D., and Robert L. Kaufman. 1982. "Economic Dualism: A Critical Review." American Sociological Review 47:727-39.

Jacoby, Sanford M. 1983. "Industrial Labor Mobility in Historical Perspective." Industrial Relations 22:261-81.

1984. "The Development of Internal Labor Markets in American Manufacturing." Pp. 23-70 in Internal Labor Markets, edited by Paul Osterman. Cambridge, Mass.: MIT Press.

1985. Employing Bureaucracy: Managers, Unions, and the Transformation of Work in American Industry, 1900-1945. New York: Columbia University Press.

Jones, John Paul. 1945. "Industrial Relations Reviewed." Personnel Journal 23 (8): 312-19.

Kahn, Lawrence M. 1976. "Internal Labor Markets: San Francisco Longshoreman." Industrial Relations 15:333-37.

Kirkpatrick, Forrest H. 1945a. "Better Personnel Administration." Personnel Journal 24:231-40.

- 1945b. "Personnel Problems after Victory." Personnel Journal 23:340-50.

Kochan, Thomas A., and Peter Cappelli. 1984. "The Transformation of the Industrial Relations and Personnel Function." Pp. 133-62 in Internal Labor Markets, edited by Paul Osterman. Cambridge, Mass.: MIT Press.

Krasner, Stephen D. 1984. "Approaches to the State: Alternative Conceptions and Historical Dynamics." Comparative Politics 23:223-46.

Kushnick, William H. 1945. "A New Challenge to Personnel Administration." Personnel Administration 7 (10): 4-7.

Lawrence, Paul. 1984. "The History of Human Resource Management in American Industry." Paper presented at annual meeting of the Academy of Management, Boston.

McQuitty, Louis L. 1947. "Principles of Manpower Utilization." Personnel Journal 25:302-10.

Martell, Charles F., Jr. 1954. "Employer Personnel Practices in the United States prior to 1930." Ph.D. thesis, Stanford University, Department of Economics.

Meyer, John W., and Brian Rowan. 1977. "Institutionalized Organizations: Formal Structure as Myth and Ceremony." American Journal of Sociology 83:340-63.

Meyer, Marshall, and M. Craig Brown. 1977. "The Process of Bureaucratization." American Journal of Sociology 83:364-85.

National Industrial Conference Board (NICB). 1927. Industrial Relations in Small Plants. New York: NICB.

- 1928. The Economic Status of the Wage Earner in New York and Other States. New York: NICB.

- 1936. What Employers Are Doing for Employees. New York: NICB. 1940. Personnel Activities in American Business. Studies in Personnel Policy no. 20. New York: NICB. 
1946a. The Business Outlook for 1947. Studies in Business Economics no. 7. New York: NICB.

. 1946b. Organization of Personnel Administration. Studies in Personnel Policy no. 73. New York: NICB.

. 1947. Personnel Practices in Factory and Office. Studies in Personnel Policy no. 86. New York: NICB.

1954. Personnel Practices in Factory and Office. Studies in Personnel Policy no. 145. New York: NICB.

National Roster of Scientific and Specialized Personnel. 1946. "The Profession of Personnel Administration." Personnel Journal 24:265-72.

Parks, Donald S. 1936. "1936 Personnel Trends." Factory Management and Maintenance 12:39.

Pfeffer, Jeffrey, and Yinon Cohen. 1984. "Determinants of Internal Labor Markets in Organizations." Administrative Science Quarterly 29:550-73.

Pierce School. 1935. Current Personnel Practices. Philadelphia: Pierce School of Business Administration.

Piore, Michael J. 1982. "American Labor and the Industrial Crisis." Challenge 25 (March-April): 5-11.

- 1983. "Can the American Labor Movement Survive Re-Gomperization?" Pp. 30-39 in Proceedings of the Thirty-fifth Annual Meeting, edited by Barbara D. Dennis. Madison, Wisc.: Industrial Relations Research Association.

Rubery, Jill. 1978. "Structured Labor Markets, Worker Organization and Low Pay." Cambridge Journal of Economics 2:17-36.

Scott, Dow, Diana Deadrick, and Stephen Taylor. 1983. "The Evolution of Personnel Research." Personnel Journal 62:624-29.

Silberman, Amachai. 1983. "Political Behavior in Organizations: The Case of the Personnel Manager." Master's thesis, University of Wisconsin-Madison, Department of Sociology.

Slichter, Sumner. 1919. The Turnover of Factory Labor. New York: Appleton.

Stark, David. 1980. "Class Struggle and the Transformation of the Labor Process." Theory and Society 9:89-130.

Steiber, Jack. 1959. The Steel Industry Wage Structure. Cambridge, Mass.: Harvard University Press.

Stinchcombe, Arthur. 1965. "Social Structure and Organizations." Pp. 142-93 in Handbook of Organizations, edited by James G. March. Chicago: Rand McNally.

Stone, Katherine. 1974. "The Origins of Job Structures in the Steel Industry." Review of Radical Politics and Economics 6:113-73.

Sweeney, Vincent O. 1956. The United Steelworkers of America. Indianapolis: no publisher.

Timmons, B. F. 1931. Personnel Practices among Ohio Industries. Columbus: Ohio State University Press.

Tolbert, Pamela S., and Lynne G. Zucker. 1983. "Institutional Sources of Change in the Formal Structure of Organizations: The Diffusion of Civil Service Reform, 1880-1935." Administrative Science Quarterly 28:22-39.

Tyerman, David. 1945. "Manpower and the Future." Personnel Journal 24:78-80.

U.S. Bureau of the Census. 1938. Biennial Census of Manufactures for 1935. Washington, D.C.: Government Printing Office.

. 1950. Census of Manufactures: 1947. Vol. 1, General Summary. Washington, D.C.: Government Printing Office.

- 1975. Historical Statistics of the United States: Colonial Times to 1970. Washington, D.C.: Government Printing Office.

U.S. Bureau of Labor Statistics. 1940-45, 1947. Monthly Labor Review. Washington:

D.C.: Government Printing Office. 
1949. Occupational Outlook Handbook. Bulletin no. 940. Washington, D.C.: Government Printing Office.

Wallace, R. F. 1946. "Job Analysis, Description and Classification." Personnel Journal 25:18-31.

Walters, J. E. 1945. "What War Industries Have Learned about Personnel Administration." Personnel Administration 7 (6): 9-12.

War Production Board (WPB). 1942. Job Instruction: A Manual for Shop Supervisors and Instructors. Washington, D.C.: War Production Board.

- 1943. Suggestion Systems. Washington, D.C.: Government Printing Office. . 1945a. Basic Guide for Labor-Management Committees. Washington, D.C.: Government Printing Office.

- 1945b. A Handbook on Wage Incentive Plans. Washington, D.C.: Government Printing Office.

Williamson, Oliver E. 1975. Markets and Hierarchies: Analysis and Antitrust Implications. New York: Free Press.

Zerba, Joseph E. 1945. "Personnel and Job Analysis Data." Personnel Journal 24:11418. 